\title{
THE INTERNATIONAL LEGAL DEFINITION OF PIRACY AND ITS MOTIVES
}

\author{
Ahmad Almaududy Amri \\ Australian National Centre for Ocean Resources and Security (ANCORS) \\ University of Wollongong, NSW, Australia \\ (aaa799@uowmail.edu.au)
}

\begin{abstract}
Piratical acts have evolved from time to time. The motives and intention of the pirates varies ranging from petty theft to collecting ransoms. Some piracies are more dangerous than the others as the equipment used to conduct the act also differs from one act to another based on the seriousness of the case. Measures have been taken to eradicate the problem of piracy. One of the measures taken was to define the problem and criminalize the act. The definition of piracy has gone through different stages. The legal definition of piracy started from the Harvard Draft Convention on Piracy which was designed in 1930s. Then it was adopted by the International Law Commission which drafted the Convention on the High Seas. The latest work involving the definition by the United Nations was the UNCLOS where it defined piracy in Article 101. The purpose of this article is to understand the motives of piracy and to explain the different legal definitions of piracy that has been adopted by the international community today.
\end{abstract}

Keywords: piracy, legal definition, international law

\section{Introduction}

The act of piracy has evolved from time to time. The seriousness of the cases is widely affected by the equipment used to conduct the attacks. Furthermore, the target of the attack also influences the process of the piratical act. Indeed, piracy has been a huge concern for a state or group of states both at the regional as well as international level. States have taken numerous efforts to eradicate the problem. One of those important measures is defining the act of piracy itself.

The development in the legal definition of piracy started in the 1930s where the Harvard Research Group drafted the complex definition of piracy (Article 3 of the Harvard Draft). The definition then was reviewed and renewed by 
the International Law Commission (ILC) where international law was reviewed by the General Assembly in relation to law of the sea. Their works were greatly affected by the works of the Harvard Research Group especially articles related to piracy. The High Seas Convention, which was one of the primary works regulated by the ILC, defined piracy in Article 15 that was agreed upon in 1958 in Geneva. The latest work in the development of a definition that is accepted by most of the states in the world is contained in Article 101 of the UNCLOS.

\section{Sea based Crimes}

Piracy could be understood by analyzing its nature and grouping it separately from other criminal acts at sea. Dillon suggested to create new categories of sea based crimes that would ease the policy makers in prosecuting perpetrators. She categorized it into four categories: corruption, sea robbery, piracy and maritime terrorism (Dillon, 2005: p. 157).

Dillon believes that there is an element of corruption when government authorities are involved in the extortion of marine vessels. Crews are asked to pay an amount of money as they are accused of violating rules related to the environment and safety. Furthermore, as it takes time to resolve the issue, crews also have to pay fines for parking their ships at harbors. Another issue that involves the government is that seaport authorities are not responding to complaints or are late in processing the villains. For example, a problem occurred in 2003 at Chittagiong, Bangladesh, to the tanker called Jaladood (Dillon, 2005, p. 158). It was reported that pirates illegally entered the tank and stole several things on the ship. After the incident, the crew informed the authorized person and there was no response. At another time, the same incident happened to a tanker called Bunga Siantan. The only difference was that the police came to arrest the culprits but unbelievably they let the pirates go after they were caught.

The second category, sea robbery, is usually executed when vessels or ships are anchored at ports. People who are involved mainly use simple kinds of equipment such as sledgehammers and crowbars. Robbers aim to steal the ship stores and the crew's valuable belongings. In 2003, a sea robbery was committed on a carrier called Alberto anchored in Panjang, Indonesia (Dillon, 2005, p. 159). They tried to steal the engine spare parts but fortunately the police caught the robbers.

The next category is piracy. Pirates usually board moving ships on their way to a designated place. This action is conducted on the high seas. Piracy is usually done by group of people or criminal syndicates that are usually well organized and equipped. They are usually equipped with weapons such as guns and knives used in conducting their attacks. In 2003, the cargo ship Trimaggada was forced to stop by pirates while passing through the Straits of Malacca with 
pirates kidnapping the master, chief officer and chief engineer of the ship (Dillon, 2005, p. 160). The pirates released them after receiving the ransom.

The last category maritime terrorism is a sea based crime that is motivated by a political motive. Terrorists try to instill fear on relevant authorities, especially the government, by doing several actions such as terror and murder. They are well organized and conduct their actions by using advanced weaponries. An example of maritime terrorism was the bombing of the US warship Cole in 2000 at Aden, Yemen that killed 17 US citizens (Romero, 2003, p. 597).

\section{What is Piracy?}

\section{Term}

The term 'piracy' originates from the Greek word peirates and was used to refer to people who attacked ships (Johnson et al., 2005, p. x). According to Vagg, an English criminologist, acts of piracy are similar to acts of banditry (Vagg, 1995, p. 64) with the only difference being that piracy occurs on water. Other scholars have proposed that piracy more closely resembles armed robbery - with both offences involving violence or criminal acts which occur in areas lacking government control (Johnson et al., 2005, p. x). Indeed, piracy is often perpetrated in developing countries where governments and law enforcement authorities do not have the capability or the will to intervene in such acts.

\section{Privateering}

Privateering should be differentiated with piracy, as the latter has been considered illegal according to international law. In the olden times, privateering was considered legal as the attack committed was permitted by a government authority. Privateering was practiced by private companies during war times where they were asked to attack and capture enemy ships upon the consent of the ruling government. These actions were legitimate and the government provided letters of marque to authorize the seizure (Geneva Academy, 2012, p. 11). Privateers were not pirates and therefore privateering was legal whereas piracy remained illegal. However, in 1856 the act of privateering was abolished. The Paris Declaration Respecting Maritime Law became the legal reasoning for this abolishment (Geneva Academy, 2012, p. 11). It was because of the inappropriate use of these authorizations by the privateers that made the government decide to eliminate privateering. Privateers were known to be greedy and used their powers for their personal enrichment.

\section{Pirates as Hostis Humani Generis}

The act of piracy is considered a universal crime which means that every state has the right to take appropriate measures to prosecute the perpetrators. The main 
reason behind this idea is due to the nature of the act itself. A piratical act is categorized as such if it is committed on the high seas, an area where every state enjoys the freedom of navigation. This notion is also reflected in the S.S. Lotus case between Turkey and France. In 1927, the Permanent Court of International Justice justified piracy as an act against 'the law of nations' (Campbell, 2010, p. 21). Turkey challenged the court to give a judgment as to whether they were allowed to exercise criminal jurisdiction over French officers. A S.S. Lotus officer was accused of being negligent that resulted in a collision with a Turkish steamer. Disagreeing on this point, France argued that the jurisdiction of the vessel was under the state flag as the incident took place on the high seas. In responding to this argument, the Permanent Court referred to the concept popularized by the Dutch lawyer Hugo Grotius in 1608 where the 'freedom of the seas' meant that every state enjoys the freedom of navigation (Campbell, 2010, p. 20). However, there was an exception to this concept. The court continued that in the case of piracy or in extraordinary cases of self-defense, 'in its jurisdictional aspect, is sui generis' (Campbell, 2010, p. 20).

In Europe, acts of piracy are also considered hostis humani generis or 'enemies of all mankind' (Harrelson, 2010, p. 291). Piracy was regarded as a threat to many people around the world especially for western cultures. Piracy was also considered as hostis humani generis by the United States. In 1820, the US Supreme Court declared that the act of piracy was hostis humani generis and therefore any state has the right to prosecute the act (Harrelson, 2010, p. 291). As a result, pirates were subjected to universal jurisdiction meaning that every state was given the right to take appropriate action even though the act of piracy was not committed within the state's jurisdiction.

Universal jurisdiction is one of the unique concepts of international law where states are entitled to exercise jurisdiction in an area outside their jurisdiction (Campbell, 2010, p. 21). In most of the cases international law only allows states to enforce their jurisdiction over territories that belong to them or over their own citizens who commit crimes. Furthermore, the state's right to implement jurisdiction over other state's territory is strictly limited. Interestingly, this provision of the international law does not apply to piracy. In contrast, states are allowed to exercise their jurisdiction on the high seas and over any national as piracy is an illegal act considered hostis humani generis (Campbell, 2010, p. 21). Hence, it is legitimate under the international law that a state could undergo appropriate measures toward the culprits.

\section{Piracy as a Threat}

Much research has categorized maritime piracy as a non-traditional threat. In the post-cold war era, piracy is regarded as one of the non-traditional treats which 'arise from factors or actors which are sub-state or trans-state in character, are 
diffuse, are multi-dimensional and multi-directional, cannot necessarily be managed by traditional military means, and often threatening to something beside the state' (Terriff et al., 1999, p. 135). In contrast, the characteristic of the traditional threat mainly affects the security of the state.

The transnational nature of piracy requires states to cooperate in order to combat the illegal act. Unilateral actions of a state and also bilateral ties between states are often believed inadequate to resolve the issue (Shie, 2006, p. 164). As piratical acts are complex in characteristics, it is required that states cooperate on multilateral levels consistently and comprehensively.

In past research as well as discussions, historical backgrounds of piracy are elaborated broadly. Several researchers, including Young (2005), believed that the history of piracy itself has a significant role in addressing contemporary piracy comprehensively (Young, 2005, p.1).

It is complex to define pirates as a term referring to 'enemy combatants' and 'common criminals'. However, there are ways used to understand this concept. Differentiating piracy from other illegal acts and observing the motive behind illegal acts of piracy in terms of time and place are some of the measures used. As mentioned by Young (2005), piracy should not be treated as a 'thing' and 'static in moral judgement (p.3). It should be looked as 'a concept to change over time which was also described by Campo as 'a concept in development' (Young, 2005, p.3). According to Hugo Grotius, piracy should be regarded as illegal acts against 'lawful commerce and state's sovereignty' (Young, 2005, p.3).

\section{The International Legal Definition of Piracy}

\section{The Harvard Draft}

The legal formulation of piracy started in the 1930s when the Harvard Research Group attempted to define the complexities of piracy (Geneva Academy, 2012, p. 12). The significant part of the discussion was the consideration of 'special jurisdiction' as a tool to prosecute the act of piracy. This group was led by an American scholar Joseph Bingham from Stanford University (Campbell, 2010, p. 23). Their work successfully produced in 1932, was known as the 'Harvard Draft'. This draft contained nineteen articles and associated commentaries on piracy. The definition, which forms the vital part of this Draft, was the initial source of today's modern definition of piracy (Geneva Academy, 2012, p. 12). There are two significant features of the Harvard Draft. Firstly, this draft went through numerous analyses and the group consulted with different views from several national courts and competent jurists (Campbell, 2010, p. 24). At that time, the draft was relevant and comprehensively accommodated aspects of piracy from different views. Secondly, the Harvard Draft formed the foundation of the modern 
concept of piracy embedded in Geneva Convention on High Seas as well as UNCLOS 1982 (Campbell, 2010, p. 26).

\section{High Seas Convention}

Further development of the piracy law took place when the UN General Assembly asked the International Law Commission to review and draft conventions related to the law of the sea based on the prevailing international customary law (Campbell, 2010, p. 27). This process was held in 1950 when the commission also was also hugely influenced by the Harvard Draft especially in drafting laws related to piracy. As a result, the commission was able to prepare four draft conventions on the law of the sea. One of the conventions drafted was the Geneva Convention on the High Seas where the definition of piracy was included. Later on in 1958, these conventions were agreed upon at the first meeting of the United Nation Conference on Law of the Sea that took place in Geneva.

UNCLOS identically restates the definition of piracy drafted by the commission in articles 14-20 of the High Seas Convention (Barrios, 2005, pp. 149164). Most of the UN member states are either a party to UNCLOS or the High Seas Convention. Therefore, the perceptions of the legal definition of piracy today in most of the states are similar (Geneva Academy, 2012, p. 14).

\section{United Nation Convention on Law of the Sea}

The Security Council has repeatedly reaffirmed that, "international law, as reflected in UNCLOS, regulates the legal framework applicable to combating piracy and armed robbery at sea, as well as other ocean activities" (Security Council resolution 1897, adopted on 30 November 2009). The United Nations in particular has regulated the problems of piracy in Articles 100 to 107. Article 100 of UNCLOS has defined piracy as an illegal act "on the high seas or in any other place outside the jurisdiction of any state" and also obliges "all states to cooperate to the fullest possible extent in the repression of piracy" (Article 100 UNCLOS 1982, came into force in 1994).

UNCLOS has defined piracy in article 101 that consists of five elements. The definition itself is quite narrow and restricts some illegal activities at sea to be defined as piracy. An act can only be categorised as piracy if it entails: First, violence, detention or depredation committed; second, the act conducted on the high seas where states do not have sovereignty nor sovereign rights over the maritime area; third, there should be two ships involved in the action, therefore there should be another ship used by the pirates in the attack of the targeted ship. Illegal acts such as mutiny and privateering are not categorized as piracy; fourth, piracy should be conducted on behalf of the private sector where the economic gain from successfully pirated ships will be enjoyed by private ends; fifth, the 
vessels used to conduct piracy should be a private vessels (Johnson et al., 2005, p. xi).

\section{Jurisdiction of the Economic Exclusive Zone}

There have been debates as to what qualifies the EEZ as a part of high seas when dealing with the act of piracy. Interestingly, UNCLOS defined the high seas in two different ways. Some parts of UNCLOS refer to the area outside the territorial as high seas. This definition includes the contiguous zone as well as the EEZ. The other definition is derived from Article 86 which states that the high seas includes all parts of the sea except the EEZ, territorial sea, internal waters and archipelagic waters. This debate arises due to the existence of some rights that could be enjoyed not only at high seas but also in the EEZ. According to Article 58 (1) of UNCLOS, every state whether it is land locked or coastal state has the right of freedom of navigation, over flight, laying submarine cables as well as 'other internationally lawful uses of the sea'(Article 58 (1) UNCLOS 1982, came into force in 1994) in the EEZ.

Another issue that forms a part of the debate is related to the jurisdiction of maritime zones that is in accordance to Article 101 (a) (i) which states that the act of piracy is conducted against ships or aircrafts on high seas. The question is whether the EEZ is also regarded as the high seas because of the navigational right embraced by Article 58. This debate on whether to consider the EEZ as part of high seas or as a separate maritime zone is clarified by Article 58 (2). This Article elaborated that the content of Articles 88 to 115, including the acts piracy and other international maritime law provisions, applies to the EEZ so long as they are not incompatible with the provision of Part V. In other words, if one of the illegal acts stipulated in Article 101 is conducted outside the area of territorial sea that is the contiguous zone and the EEZ, such an act is considered piracy.

\section{International Maritime Organization and International Maritime Bureau}

The International Maritime Organization (IMO) and the International Maritime Bureau (IMB) have defined piracy in different ways. IMO as a body under the UN adopts the definition of piracy from UNCLOS. On the other hand, IMB also defines the act of piracy. Compared to IMO, IMB's definition is broader and almost covers all attacks against ships in all maritime jurisdictions of a state. The IMB explained piracy in three different elements: first, there should be an act committed by the crew or the passenger of the ship to board or attempt to board any ship; second, the motive of this act is to commit theft or any other crime; finally, there should be an attempt or capability to use force in furtherance of that act.

It is clear that the IMB defined piracy broader than the IMO. Requirements such as the act should be committed only on the high seas in order to be 
categorized as piracy was waived by the IMB. Furthermore, the involvement of two ships in its conduct is also ignored by the IMB definition that allows the attack from raft and quays as part of piracy. In addition, there is no limitation that an act should be committed for private ends. Hence, if the motive of the criminal act is political or regarded to have environmental motives, it will still be categorized as piracy. Therefore, the attack against Achille Lauro according to the IMB definition regarded as an act of piracy (Johnson, 2005, p. xii). Interestingly, actions committed by naval ships, which most of the time are under a nation-state's agenda, can also be categorized as piracy if can be proven that it committed a criminal act under the definition of the IMB.

\section{Motives of Piracy}

\section{Theft, Hijacking and Collecting Ransoms}

Historically, the main goal of piracy was raiding for booty and slaves, but as there were developments in politics, economics and militaries, piratical raiding decreased. Pirates have become more intelligent over time. Their actions could be classified as theft and hijacking. As for theft, several decades ago, pirates stole things that were not of high value (Mukundan, 2005, p. 37). Their targets were limited to the valuable things owned by the captains and other crew members. Furthermore, they also tried to take away the ship equipment and other goods which belonged to the ship and which were easily taken. Today, pirates are more determined and equipped with armed weapons. They are well planned and know exactly what their targets are.

Hijacking is the other form of piracy. Pirates aim to attack a vessel and try to transfer its cargo to another ship. The targeted ship movement is well monitored by the pirates and therefore they can take control of their target professionally. This kind of hijacking does occur when the value of both the ship and its cargos are high. Pirates are not only equipped with guns but also other weapons such as knives. They have the skills to navigate a ship without the presence of crew members. Pirates often provide fake ship papers, cargo papers and even passports in order to ease their piratical action. There is no guarantee to the treatment of the crew members by the pirates. Some crew members are intimidated and tortured while others are killed. Prominent examples to illustrate these facts were the cases of piracy to Cheongson and Tenyu. The 1998 IMB Annual Piracy Report published that all crew members were killed during the attacks (Mukundan, 2005, p. 37). 
Types of Arms used during Attacks, January-December 2008-2012

\begin{tabular}{|l|c|c|c|c|c|}
\hline Types of Arms & $\mathbf{2 0 0 8}$ & $\mathbf{2 0 0 9}$ & $\mathbf{2 0 1 0}$ & $\mathbf{2 0 1 1}$ & $\mathbf{2 0 1 2}$ \\
\hline Guns & 139 & 243 & 243 & 245 & 113 \\
\hline Knives & 68 & 71 & 88 & 69 & 73 \\
\hline Not stated & 80 & 90 & 108 & 117 & 104 \\
\hline Other weapons & 6 & 6 & 6 & 8 & 7 \\
\hline Total at year end & 293 & 410 & 445 & 439 & 297 \\
\hline
\end{tabular}

Source: ICC IMB, 2012, p. 10

Before 2001, merchant ships were the main targets of pirate attacks as it was an easy target to steal valuable belongings of crews as well as cargo. However, after 2001 there were several cases which were successfully recovered and the pirates were punished appropriately, especially in India and China. Therefore, there were groups of pirates who were looking for easier targets such as attacks on tugs and barges. According to Mukundan (2005), barges usually carry palm oil and timber products that are also of high value (p. 38).

Collecting ransoms from the related authorities is also another motive of piracy. There were several cases that involved ransom as the tool of compromise. For instance the activities conducted by terrorist groups in the southern part of the Philippines. The culprits captured several crews and asked for ransom for their release. Another case that was similar took place in Malaysia on August 2003 where the Malaysian tanker Penrider was hijacked by a group of pirates (Mukundan, 2005, p. 38). The pirates abducted the crew members and asked for ransom.

\section{Conclusion}

The legal definition of piracy has gone through several stages. It started with the work of the Harvard Research Group which produced the Harvard Draft. Then the International Law Commission produced the High Seas Convention, with the latest work by UN in the UNCLOS. Even though the development of the definition of piracy occurred in different stages, the Harvard Draft remains the main foundation of the definition of piracy today as its content hugely influenced the latter two documents. The IMB has also tried to define piracy. However, its definition is broader and is primarily used for piracy reporting purposes not for criminalizing the act.

Theft, collecting ransoms and hijacking are the primary motives of piracy. The weapons used to conduct the act differ based on its motives. Hence, piracy with intent to steal valuable belongings of the crews is not more dangerous than hijacking of a merchant ship. Furthermore, during the act, there is no guarantee to the life of the crews. They could be intimidated, tortured and in some cases killed. 


\section{References}

Barrios, E. (2005). Casting a wider net: Addressing the maritime piracy problem in Southeast Asia. BC Int'l E Comp. L. Rev, 149-164.

Campbell, P. (2010). A Modern history of the international legal definition of piracy. Piracy and Maritime Crime, 20-32.

Dillon, D. (2005). Maritime piracy: Defining the problem. SAIS Review, 155-164.

Geneva Academy. (2012). Counterpiracy under International Law. Geneva: Villa Moynier.

Harrelson, J. (2010). Blackbeard meets blackwater: An analysis of international conventions that address piracy and the use of private security companies to protect the shipping industry Am. U. Int'l L. Rev., 283-312.

ICC International Maritime Bureau. (2012). Piracy and Armed Robbery Against Ships. ICC International Maritime Burea, 1-87.

Johnson, D., Pladdet, E., \& Valencia, M. J. (2005). Introduction: Research on Southeast Asian piracy. In D. Johnson \& M. J. Valencia (Eds.), Piracy in Southeast Asia: Status, issues, and responses. Singapore: Institute of Southeast Asian Studies.

Mukundan, P. (2005). The Scourage of Piracy in Southeast asia: Can Any Improvements be Expected in the Near Future?. Piracy in Southeast Asia: Status, Issues, and Responses, 34-44.

Romero, J. (2003). Prevention of maritime terrorism: The container security initiative. Chicago Journal of International Law.

Shie, T. (2006). Maritime piracy in Southeast Asia: The evolution and progress of Intra-ASEAN Cooperation. In G. Gerard and O. Webb (eds.), Piracy, maritime terrorism and securing the Malacca Straits. ISEAS Publishing.

Terriff, T., Crofty, S., James, L., Morgan, Patrick, M. (1999). Security Studies Today. Cambridge: Polity Press.

Vagg, J. (1995). Rough seas? Contemporary piracy in South East Asia. British Journal of Criminology.

Young, A.J. (2005). Roots of contemporary maritime piracy in Southeast Asia. In D. Johnson and M. Valencia (eds.), Piracy in Southeast Asia: Status, issues, and responses. ISEAS Publishing. 